\title{
The Effect of Tourism Facilities, Service Quality and Promotion of Tourist Satisfaction in South Pesisir District
}

\author{
Arif Mustaqim Bahar ${ }^{1}$, Maizaldi ${ }^{2}$, Novrianto Putera ${ }^{3}$, Resky Widiestuty ${ }^{4}$, Syafrianto Chaniago ${ }^{5}$, Yulina Eliza ${ }^{6}$ \\ Sekolah Tinggi Ilmu Ekonomi \\ "KBP” J1. Khatib Sulaiman No. 61 Padang \\ Correspondence email: yulinaeliza@akbpstie.ac.id
}

\begin{abstract}
The purpose of this study was to determine the effect of tourism facilities on tourist satisfaction in South Coastal District, to determine the effect of service quality on tourist satisfaction in South Coastal District, to determine the effect of promotion on tourist satisfaction in South Coastal District. The method used is a quantitative research using descriptive, while the data collection used questionnaire. The sampling technique is non probability sampling with a type of purposive sampling of 115 respondents. The results of this study can be concluded that the: (1) Tourism facilities has a positive and significant effect on tourist satisfaction in South Coastal District. (2) Service quality has a positive and significant effect on tourist satisfaction in South Coastal District. (3) Promotion has a positive and significant effect on tourist satisfaction in South Coastal District.
\end{abstract}

Keywords: Tourist Facilities, Service Quality, Promotion, Tourist Satisfaction

\section{Introduction}

The potential of Indonesian tourism which is quite attractive to tourists, one of which is in West Sumatra is dominated by natural attractions such as lakes, waterfalls, valleys, mountains, beaches, caves, hot spring baths and also historical and cultural tourism is also one of the tours that has its own attraction for tourists, especially for foreign tourists who are so interested in the original culture of Minangkabau and Mentawai. Some areas in West Sumatra that must be visited by tourists who have tourism icons include the city of Padang, Bukittinggi / Agam, Payakumbuh / 50 Cities, Padang Panjang, Solok City, Sawahlunto, Kab. Pesisir Selatan, Kab. Pariaman, Kab. Mentawai and West Pasaman. Consumer satisfaction is an issue that is a major concern for most companies such as issues about services that are less than the maximum so that consumers feel a lot of disappointment both in terms of administration, amusement rides, to other facilities. The fact of the last three years a decline in the number of tourist visits to attractions in the South Coastal District, can be seen in the following table:

Table 1

Number of Tourist Visits on Attractions in Pesisir Selatan Regency

\begin{tabular}{llrrr}
\hline No & Tourist attraction & \multicolumn{3}{c}{ Number of visits (people) } \\
\\
\hline 1 & Carocok Painan & 2015 & 2016 & 2017 \\
2 & Mandeh & 400.775 & 18.556 & 202.521 \\
3 & Jembatan akar & 20.180 & 9.325 & 17.330 \\
4 & Bayang sani & 12.657 & 1.467 & 8.954 \\
Total & & 1.510 & 283.668 & 1.187 \\
\hline
\end{tabular}

Source: Department of Tourism, Youth and Sports in Pesisir Selatan District, 2019

The research objective is to determine the effect of tourist facilities on tourist satisfaction in the South Coastal District, to determine the effect of service quality on tourist satisfaction in the South Coastal District and to determine the effect of promotion on tourist satisfaction in the South Coastal District. To determine the effect of tourist facilities, service quality and promotion simultaneously on tourist satisfaction in the South Coastal District

\section{Literature Review}

Kotler and Keller (2012) define satisfaction as one's feelings of pleasure or disappointment over the results comparing the perceived product performance with expectations. According to Zhu, et al (2012) satisfaction is a cognitive and affective reaction to service / service incidents or sometimes to long-term relationships, so satisfaction or dissatisfaction results from service quality interaction experiences and comparison of interactions with expected. According to Lupiyoadi (2013), there are five factors that must be considered to determine the level of satisfaction, namely, product quality, service quality, emotional, price and cost. Kuo, et al (2009), explains satisfaction is influenced by the level of expectation of service quality. Whereas Wanda and Pangestuti (2018) state that tourist visitor satisfaction can be measured by indicators namely attractions, facilities and services, accessibility, tourism object image and cost or price. Aliman, et al (2014) state that tourist satisfaction itself can be measured through indicators: 1) enjoying the visit, 
2) satisfied with the decision to visit, 3) liking the destination, 4) feeling satisfied, 5) the need for experience, 6 ) wisdom in choosing a trip, 7) pleasant visits, 8) visits exceeding expectations, and 9) comparison of destinations. From the expert opinion above, it can be stated the focus of tourist satisfaction indicators in this study, namely attractions, facilities and services, accessibility, tourism object image and cost or price.

Tourist facilities according to Mill in Gusneli, et al (2016) are supporting services that are always ready to be utilized by tourists and these services offer quality and prices that are in line with tourist needs. According to Yoeti in Teguh, et al (2015: 3) tourism facilities are all facilities whose function is to meet the needs of tourists who live in tourist destinations that are visited temporarily, they enjoy casually and participate in activities available in tourist areas. From the expert opinion above, it can be stated the focus of tourism facility indicators in this study namely Accommodation Units, Restaurants, Bars and Cafes, Transports at the Destination, Sports and Activities, Other Facilities, Retail Outlets, and Other Services.

According to Lupiyoadi (2013), quality is the overall characteristics and characteristics of a product / service in terms of its ability to meet predetermined or latent needs. Quality of service must be done by the company in order to survive and continue to get customer trust. Kotler and Keller (2012), define service quality as the ability of feelings to satisfy the needs and desires of consumers. The service quality approach that is often used as a reference in marketing research is the SERVQUAL (Service Quality) model. Ryu, et.al (2012), mentioned that there are five dimensions of SERVQUAL (service quality). The five dimensions of service quality are Tangible, Empathy, Reliability, Responsiveness (responsive or responsive), and Assurance (reliability). Kotler (2012) mentions five dimensions of service quality that must be met, namely: 1) Physical evidence; 2) Empathy; 3) Reliability; 4) Quick response; 5) Guarantee.

From the expert's opinion, it can be stated that the focus of service quality indicators in this study are tangible (physical facilities, equipment, and means of communication from the surrounding community and tourism management), empathy (empathy), reliability (ability to provide services), responsiveness (desire to help tourists), and assurance (knowledge, abilities, and trustworthiness of the official of the service and surrounding communities). Kotler and Armstrong (2012), express promotion as an activity of communicating the benefits of a product and persuading consumers to buy the product. Hermawan (2012) suggests promotion as a priority component of marketing that informs consumers that a company is launching a new product so consumers are tempted to buy it. There are five promotional activities expressed by Kotler and Armstrong (2012), including Advertising, Sales promotion, Personal selling, Public relations, and Direct marketing. According to Miftakul (2017: 9), indicators used in the promotion of products or services are sales promotion and public relations. From the expert's opinion, it can be stated that the focus of promotion indicators in this study are exhibitions, advertisements and publicity, brochures, and events.

The thinking framework in this study can be seen in Figure below:

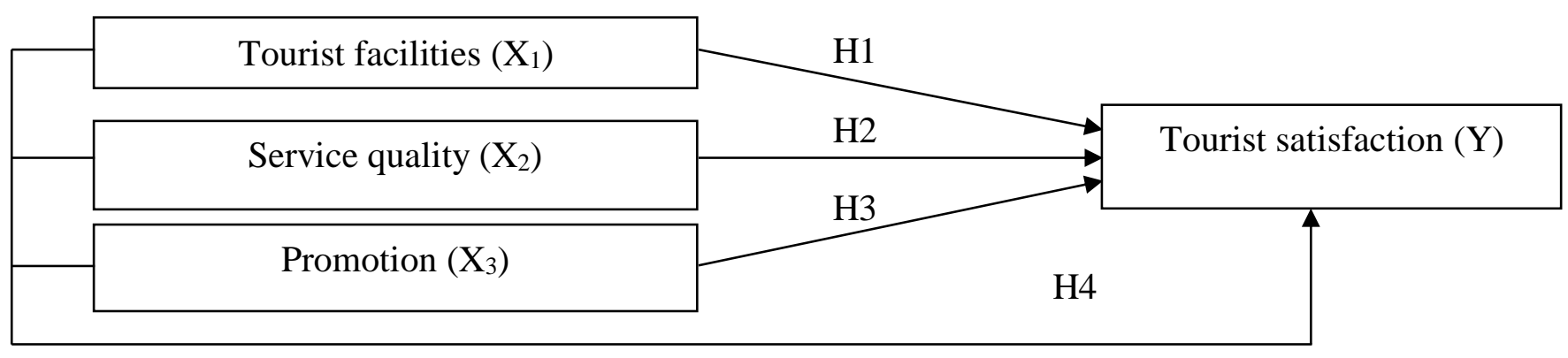

Figure 1

Research Framework

\section{Method}

The population in this study were all tourists visiting the South Coastal District in 2018 whose numbers are unknown. The method used in sampling is a non-probability sampling method with a purposive sampling technique that is the sample chosen carefully so that it is relevant to the research design. The sample selection criteria in this study are tourists visiting the South Coastal District in 2018. If the population is unknown, according to Hair et al. (2006) recommend a minimum sample size of 5 times the number of question indicators contained in the questionnaire. The indicators of this study are 23, the sample calculation results are obtained as follows: Number of Samples $=5 \times 23=$ 115 samples. Hair et, al. (2006) suggest that the research to be processed using multiple regression is a minimum sample size of 50 respondents and more than 100 respondents are recommended for most research situations. So in this study, researchers determined a sample of 115 people.

The data analysis technique used is multiple linear regression analysis. Determination of multiple regression is used by researchers with the intention to determine the magnitude of the influence of tourist facilities, service quality 
and promotion of tourist satisfaction in the South Coastal District. The equation that states the form of influence between the independent variable $(\mathrm{X})$ and the dependent variable $(\mathrm{Y})$ is called the regression equation. The coefficient of determination $\left(\mathrm{R}^{2}\right)$ basically measures how far the model's ability to explain the variation of the dependent variable (Ghozali, 2013). $\mathrm{R}^{2}$ values range from 0 to 1 . If $\mathrm{R}^{2}$ moves close to 1 , it means that there is a large variation of the dependent variable that can be explained by the independent variable. And if in the calculation of the value of R2 equal to 0 then this shows that the dependent or bound variable cannot be explained by the independent variable.

\section{Results}

To find out how much the regression coefficient of each independent variable and how the direction of its influence on the dependent variable, can be seen from the analysis of the multiple regression data obtained using the SPSS Version 21 program as shown in the following table 2

Table 2

Variable Double regression results research

\begin{tabular}{lrrr}
\hline \multicolumn{1}{c}{ Variable } & Regression Coefficient & Count t & Significance \\
\hline Tourist facilities & 0,159 & 2,546 & 0,012 \\
Service quality & 0,365 & 3,563 & 0,001 \\
Promotion & 0,213 & 2,220 & 0,029 \\
constanta & & & 8,380 \\
$\mathrm{R}^{2}$ & & 0,725 \\
$\mathrm{~F}_{\text {count }}$ & & 44,321 \\
\hline
\end{tabular}

Source: Primary data processed, 2019

Based on the regression results from Table 2 above, it can be determined that the multiple linear regression equation in this study is as follows: $\mathrm{Y}=8.380+0.159 \mathrm{X}_{1}+0.365 \mathrm{X}_{2}+0.213 \mathrm{X}_{3}$

Information: Y: Tourist Satisfaction; $\mathrm{X}_{1}$ : Tourist Facilities; $\mathrm{X}_{2}$ : Quality of Service; $\mathrm{X}_{3}$ : Promotion

The interpretation of the regression equation obtained is as follows:

1. The constant value of 8.380 with a positive sign means that even though there are no tourist facilities, service quality and promotion, the satisfaction of tourists visiting the South Coastal Regency remains at 8.380.

2. The regression coefficient of the tourism facility variable shows a positive influence on the satisfaction of tourists visiting the South Coastal District with a value of 0.159 meaning that each addition of one unit of tourist facility variable will increase tourist satisfaction by 0.159 .

3. The regression coefficient of the variable service quality shows a positive effect on the satisfaction of tourists visiting the South Coastal District with a value of 0.365 meaning that each addition of one unit of service quality variables will increase tourist satisfaction by 0.365 .

4. The regression coefficient of the promotion variable shows a positive influence on the satisfaction of tourists visiting the South Coastal District with a value of 0.213 meaning that each addition of one unit of the promotion variable will increase tourist satisfaction by 0.213 .

$t$ test is done to find out whether the hypothesis made by the author can be accepted or not by looking at the value of sig. in the coefficient table which can be seen in table 2 above. In the table above can be seen the results of the $t$ test of each independent variable on the dependent variable as follows:

1. From the processed data obtained tourist facilities $\left(X_{1}\right)$ have a significant effect on the satisfaction of tourists visiting the South Coastal District (Y). Based on table 2 sig values are obtained. $0.012<0.05$. This means that Ho was rejected and $\mathrm{Ha}$ was accepted. So it can be concluded that the tourist facilities significantly influence the satisfaction of tourists visiting the South Coastal District.

2. The results of the processed data obtained by the quality of service $\left(X_{2}\right)$ significantly influence the satisfaction of tourists visiting the South Coastal District $(\mathrm{Y})$. Based on table 42 the value of sig is obtained. $0.001<0.05$. This means that Ho was rejected and Ha was accepted. So it can be concluded that the quality of service has a significant effect on the satisfaction of tourists visiting the South Coastal Regency.

3. From the processed data also shows that the promotion $\left(\mathrm{X}_{3}\right)$ has a significant effect on the satisfaction of tourists visiting the South Coastal District (Y). Based on table 2 sig values are obtained. $0.029<0.05$. This means that Ho was rejected and Ha was accepted. So it can be concluded that the promotion has a significant effect on the satisfaction of tourists visiting the South Coastal District.

The $\mathrm{F}$ test was used to determine the effect of the independent variables together on tourist satisfaction. In table 4.10 it can be seen that the $F_{\text {count }}$ value is 44,321 with a significance of $0,000<0.05$ (alpha). This means that the variable tourist facilities, service quality and promotion together have a significant influence on the satisfaction of tourists visiting the South Coastal District. In this case the influence exerted is positive. This can be seen from the regression 
coefficient values shown by b1, b2 and b3, which are positive. The existence of a positive value indicates that if these variables are increased, it will increase the satisfaction of tourists visiting the South Coastal District.

To find out how much influence the independent variable consisting of tourist facilities, service quality and promotion of tourist satisfaction visiting the South Coastal Regency can be seen from the value of adjusted R square in table 3.

Tablel 3

Model Summary

\begin{tabular}{lrrrrr}
\hline & Model & $\mathrm{R}$ & $\mathrm{R}$ Square & Adjusted R Square & \multicolumn{1}{c}{ Std. Error of the Estimate } \\
\hline 1 & &, $752^{\mathrm{a}}$ &, 566 &, 553 & 3,064 \\
\hline
\end{tabular}

Source: Primary data processed, 2019

From Table 3 above, the adjusted $\mathrm{R}$ square value shows 0.553 , this indicates that the contribution of the independent variable to the dependent variable is $55.3 \%$ while $44.7 \%$ is determined by other factors not examined in this study.

Discussion

1. Tourist Facilities for Tourist Satisfaction

The results of data analysis and the proposed hypothesis that tourist facilities affect tourist satisfaction, means that tourist satisfaction can be influenced by tourist facilities. Tourist facilities provided include lodging or hotels, restaurants, visitor buses, guides, souvenir shops, parking lots, prayer rooms, gazebos, crossing bridges, stages, visitors' seating in tourist areas, and toilets with variable indicators of tourist facilities are in the high category . With the sense that tourists who visit are able to meet their needs through the facilities provided, which impact on the creation of customer satisfaction. In line with research conducted by Munggar (2013) and Nugraha (2013) states that there is a significant partial effect of tourism facilities on consumer satisfaction. It can be said that the facility desired by consumers to achieve customer satisfaction is a complete facility, with clean and well-maintained conditions. In accordance with the opinion expressed by Mill in Gusneli, et al (2016) that tourist facilities are supporting services that are always ready to be used by tourists and the service offers quality and prices that are in accordance with tourist needs.

2. Service Quality Against Tourist Satisfaction

The results of the analysis of the results of the data and further in accordance with the proposed hypothesis that the quality of service has a significant effect on tourist satisfaction. Viewed from a descriptive analysis that the quality of service is in the high category. With the sense that tourists feel the quality of service provided is adequate and can support tourist activities during a visit to the South Coastal District. The results of this study are in line with research conducted by Astuti (2016) stating that the quality of tourist attraction services simultaneously has a positive effect on tourist satisfaction. Service quality is one of the processes of a product to improve customer satisfaction by meeting customer needs (Jahanshahi, et al, 2011).

3. Promotion to tourist satisfaction

Based on the results of data analysis, further in accordance with the hypothesis proposed that promotion affects the satisfaction of tourists. This suggests that traveller satisfaction can be influenced by promotion. The descriptive analysis results are contained in the indicator of entry in high criteria. With the sense that high promotion will increase the satisfaction of tourists. The results of this study in line with the research conducted by Arvinia, DKK (2013) explained that the promotion is positive and significant to customer satisfaction. Ernika (2016) said tourism promotion has significant effect on the satisfaction of tourists. According to Kotler and Armstrong (2012:76), promotion is an activity that communicates the benefits of a product and persuades the consumer's target to purchase the product. While tourism promotion is an activity to tell about the beauty or uniqueness of a tourist attraction offered to prospective tourists/tourists. Khan, et al. (2012) expressed promotion to increase the satisfaction of tourists by providing advertising and new attractions affecting the refugee. Promotion achievement is able to improve end satisfaction.

\section{Conclusion}

Based on the data analysis and interpretation presented in the previous chapter, several conclusions can be drawn from the results of the study as follows:

1. Tourism facilities have a positive and significant effect on the satisfaction of tourists visiting the South Coastal District. The better the arbiter's facilities are provided, then the satisfaction of tourists increases, on the contrary the worse the tourist facilities, the satisfaction of tourists decreases.

2. The quality of service has a positive and significant effect on the satisfaction of tourists visiting the South Coastal District. That is, the higher the quality of service, the more increased tourist satisfaction, conversely the lower the 
quality of service, the lower the satisfaction of tourists.

3. Promotion has a positive and significant effect on the satisfaction of tourists visiting the South Coastal District. The more intense the promotion, the higher the satisfaction of tourists, otherwise the lack of promotion will reduce tourist satisfaction.

4. Tourist facilities, service quality and promotion simultaneously have positive and significant effect on the satisfaction of tourists visiting the South Coastal Regency.

\section{Reference}

Hair, J., Black, W., Babin, B., Anderson, R. and Tatham, R. (2006). Multivariate Data Analysis. 6th Edition. Pearson Prentice Hall, Upper Saddle River.

Jahanshahi, Asghar Afshar., Gashti, Mohammad Ali Hajizadeh., Mirdamadi, Seyed Abbas., Nawaser, Khaled., Khaksar, Seyed Mohammad Sadeq. (2011). Study the Effects of Customer Service and Product Quality on Customer Satisfaction and Loyalty. International Journal of Humanities and Social Science, Vol. 1 No. 7, 2011, 253-260.

Khan, Shahzad; Hussain, Syed Majid; Yaqoob, Fahad. (2012). Determinants of Customer Satisfaction in Fast Food Industry, International Journal of Management and Strategy, Vol. 3.

Kotler, Philip and Kevin Lane Keller. (2012). Marketing Management 13. New Jersey: Pearson Prentice Hall, Inc.

Kuo, Ying-Feng and Chi-Ming Wu. (2012). Satisfaction and Post Purchase Intentions with Service Recovery of Online Shopping Websites; Perspectives on Perceived Justice and Emotions. International Journal of Information Management, Vol. 32 Issue 2 pp 127-138.

Ryu, Kisang., Hye-Rin Lee Woo Gon Kim. (2012). The Influence of The Quality of The Phisical Environment, Food and Service on The Restaurant Image, Customer perceived Value, Customer Satisfaction anf Behaviour Intention. International Journal of Comtemporary Hospitality Manager. Emerald Insight

Zhu, Yu Qian and Houn-Gee Chen. (2012). Service Fairness and Customer Satisfaction in Internet Banking. Internet Research Vol. 22 No. 4 pp1066-2243. 